\title{
Condition Assessment and Structural Audit Before and After Repair of Fire Damaged Structure and Ansys Simulation of Column Jacketing
}

\author{
Rajat R. Singh, P. B Kulkarni, A.K. Sharma
}

\begin{abstract}
This study give details about the rehab process of fire damaged reinforced concrete buildings in basically three categories; condition evaluation, decision making, rehabilitation \& retrofitting. Evaluation process of damaged building is based on understanding of condition survey and condition assessment of fire damaged structure. Condition survey includes detailed visual inspection of building whereas condition assessment includes non-destructive testing of building (such as Rebound Hammer test, Ultrasonic Pulse Velocity test, Carbonation test, $\mathrm{pH}$ test, Half Cell Potential test etc.). Based on survey and assessment, various repair and retrofitting schemes have been suggested. RC members often need strengthening to raise their capacity to sustain the applied load. This research investigates the behavior of RC columns strengthened using RC jacket technique. A finite element model was stimulated in ANSYS WORKBENCH to study the performance of these columns with and without jacketing, which has been designed for static loading. Based on ansys simulation and Comparison of test result before and after jacketing, it can be said that structure is safe in static loading condition.
\end{abstract}

Index Terms - Non Destructive Test, Colum Jacketing, Structural Repair, Fire Damage, FEM.

\section{INTRODUCTION}

The need of testing hardened concrete has been felt for previous three to four decades. The current methods of testing fresh concrete such as slump test, cube test are now being supported by a variety of Non Destructive Testing methods. Concrete is a heterogeneous object, comprising of a combination of cement, aggregate and steel reinforcement. Each of these components has a dissimilar response to thermal exposure, and the behavior of the composite body in fire is difficult to define or else model. During high temperature, concrete shows complex behavior due to the differences in coefficient of thermal expansion of each component. To find out the amount of fire damage occurred in affected RCC members of the building, Visual assessment of a fire damage $\mathrm{RC}$ structure is done to detect the heat patterns, change in color, spaling, cracking, any visible deflection of structural element etc. Generally concrete is considered as fire resistant and non-combustible substance

Revised Manuscript Received on July 10, 2019.

Rajat R. Singh, P.G student, Civil Engineering, Shri Ramdeobaba college of Engineering and Management, Nagpur.India (E-mail: rs13011996@gmail.com)

Prof. P. B Kulkarni, Associate Professor, Civil Engineering, Shri Ramdeobaba college of Engineering and Management, Nagpur. India (Email: kulkarnipb@rknec.edu)

Dr. A.K. Sharma, Associate Professor, Civil Engineering, Shri Ramdeobaba college of Engineering and Management, Nagpur. India (Email: sharmaak@rknec.edu) but if the temperature of concrete reaches up to 300 Celsius then oxidation of iron compounds in the concrete occurs and it gives a pink color to the concrete. Pink color of concrete shows damaged concrete, concrete can't be used anymore. At more high temperature that usually does not happen in building fires, concrete changes its color to whitish grey and subsequently to yellowish-brown color at the end.

In this project, a residential and commercial building "Jagat Tower" in Nagpur caught fire. The reason of fire was short circuit in a cloth shop of basement and fire was for 7-8 hours. As a result of fire, severe damages in the structure were observed like spalling, cracking, and deformation etc of concrete members. This building is around 30 years old. Building has a basement plus six floors.

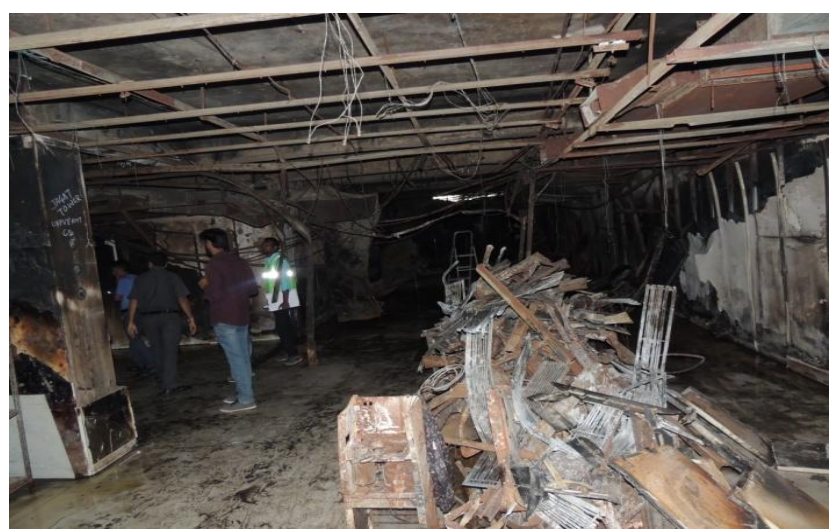

Fig. 1. Fire damaged basement

\section{CONDITION ASSESSMENT OF STRUCTURAL MEMBERS}

Condition assessment of structural members is an extremely essential part of structural audit. Structures' damage is bit technical to recognize and estimate. Structural condition assessment is done with the help of various methods which incorporate various field inspections, laboratory testing, and field testing. In the general assessment or desk study of the building the type of building and its structure is studied. Afterwards entire plan is developed for the structural assessment. With reference to BS1881: Part 201:1986

Published By:

Blue Eyes Intelligence Engineering \& Sciences Publication 


\section{CONDITION ASSESSMENT AND STRUCTURAL AUDIT BEFORE AND AFTER REPAIR OF FIRE DAMAGED STRUCTURE AND ANSYS SIMULATION OF COLUMN JACKETING}

\section{VISUAL INSPECTION}

Visual inspection is an extremely powerful tool and one of the most common and oldest on hand non-destructive testing practice available. Visual inspection provides a lot of information with reference to the structure and its condition but has certain limitations and requirements. Visual inspection can only be administrated by a technically sound professional who has understanding about structure, construction methodologies and material science. Visual inspection just gives impression of visible problem and hidden problem stays unnoticed. It also doesn't provide us any quantitative information in relation to the properties of the material. Because of these limitations, Visual inspection is not enough and has to be complemented by other nondestructive and partially destructive testing methods. With reference to BS1881: Part 201:1986

\section{SCHMIDT/REBOUND HAMMER}

A Rebound Hammer is one of the simplest or handy instruments used to compute the elastic property or compressive strength of concrete or rock, generally surface hardness and penetration resistance. For fire damage structures it has its own usefulness and limitations. The Schmidt rebound hammer works on the principle that the rebound of an elastic mass depend on the hardness of the surface against which the mass strikes. Once the plunger of the rebound hammer is pushed against the surface of the concrete, it will strike the concrete with a defined energy and the spring-controlled mass rebounds. The extent of such a rebound depends on the surface hardness of the concrete. The rebound value is read from the graduated scale and is designated as the rebound number or rebound index. With reference to the conversion chart, the rebound number can be used to find out the compressive strength. Condition of uneven or smooth surface and repetitive number of tests at the same position and no of points essential for successful testing make it very difficult to test the fire damaged concrete structures where concrete spalling and disintegration is often the case. Procedure is as per IS 13311:1992 (Part-II).

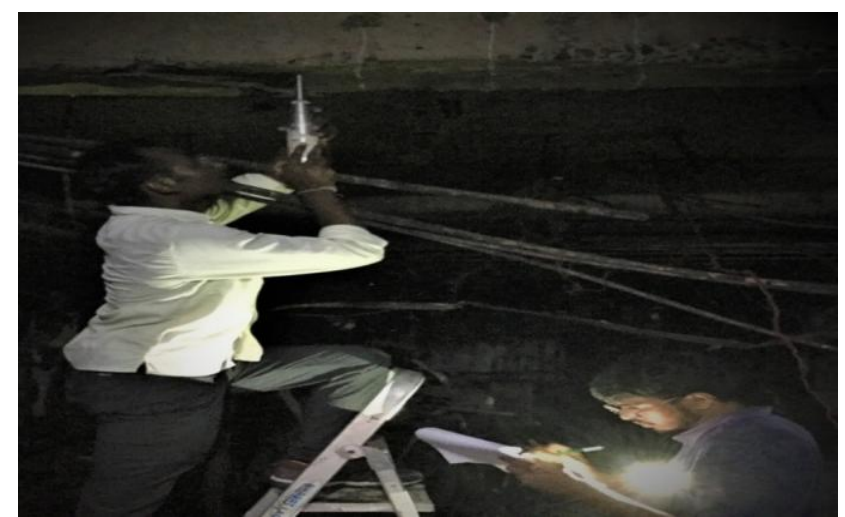

Fig. 2. Rebound hammer test

\section{ULTRASONIC PULSE VELOCITY}

It is done to evaluate the compressive strength and quality of concrete by ultrasonic pulse velocity method. This method consists of computing the time of travel of an ultrasonic pulse passing through the concrete being tested.
Relatively higher velocity is attained when concrete quality is good in terms of uniformity, density and homogeneity etc. A pulse of longitudinal vibrations is created by an electroacoustical transducer, which is kept in contact with one the surface of the concrete under test. When the pulse generated is passed into the concrete from the transducer by means of a liquid coupling material for example grease or cellulose paste, it goes through multiple reflections at the boundaries of the different material phases inside the concrete. A complex structure of stress waves develops which consist of both longitudinal and shear waves, and transmit through the concrete. The first waves to arrive at the receiving transducer are the longitudinal waves, which are transformed into an electrical signal by a second transducer. Electronic timing circuits enable the transit time $\mathrm{T}$ of the pulse to be measured. Procedure is as per IS 133111992(Part I).

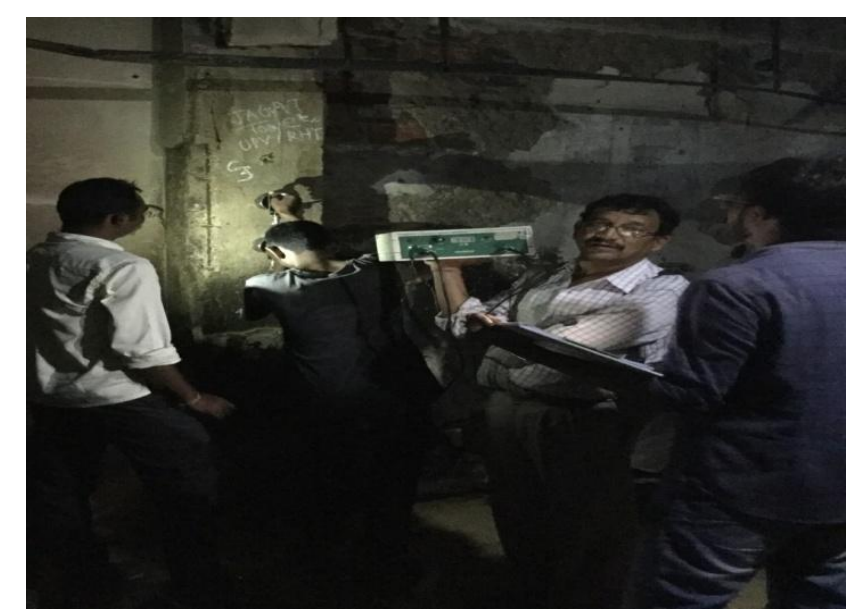

Fig. 3. Ultrasonic Pulse Velovity Test

\section{PH AND CARBONATION}

Although concrete normally begins its life at a very much basic $\mathrm{pH}$ of about 13 , the $\mathrm{pH}$ values at exposed surfaces soon drop as reactions take place between carbon dioxide from the atmosphere and alkalis in the concrete. This process is known as carbonation. In due course of time, front of carbonated concrete, with lesser $\mathrm{pH}$ values, advance beneath exposed surfaces. It is necessary to find out the depth of this front, because carbonated concrete can lead to corrosion of reinforcing steel. Carbonation depth can be known by spraying a phenolphthalein indicator solution onto a fractured or cut surface of the concrete and noting the location of a color change. The depth of the carbonation front can also be estimated by using a drill to collect samples at selected depths. The Carbonation Depth test Procedure is followed as per BS 1881 (Part 201) 1986 clause 2.2 




Fig. 4. pH and Carbonation Test

\section{HALF CELL POTENTIAL TEST}

Corrosion is an electrochemical phenomenon. In this the electrode potential of steel bar with reference to a standard electrode undergoes changes depending on corrosion acticvity. The measurement is done by giving an electrical connection to the rebar and study the voltage difference between the bar and reference electrode in contact with the concrete surface. Generally, the voltage potential becomes more negative as the corrosion becomes more active. The general guidelines are according to ASTM C 876.

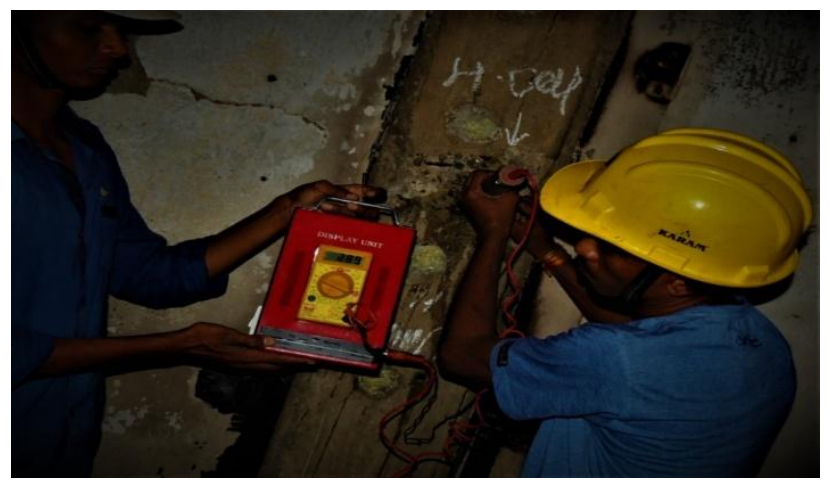

Fig. 5. Half Cell Potential Test

\section{RETROFITTING OF STRUCTURAL MEMBERS}

Structural Retrofitting is the process of structural repair through which original strength of structure is increased or installed in order that it can accomplish its intended function successfully and safely. Basic idea behind this repair method is to take out the damaged concrete by some appropriate mean (Jack hammer, hydro blasting etc.) upto the depth of damage. Subsequently remove the part of reinforcement bars that have been damaged. After concrete removal and preparation of surface, reinforcement bars that have been removed are replaced by overlapping or welding. After replacement of bars, it is important to cover healthy reinforcements with some epoxy resin which will prevent corrosion of bars, makes bonding easy and eliminate existing salts over the surface. Repaired reinforcement bars should be surround by new concrete all around to provide strong enough bond that can accommodate stress transfer between concrete and steel. Thumb rule is to provide 1 inch new concrete all around the bars.

\section{CONCRETE JACKETING}

Concrete jacketing is one of the most common retrofitting method for structural members. In fire damaged building concrete jacketing may provide additional strength to damaged structural members. It is done by removing the existing cover of the element and adding a new concrete cover along with new reinforcement bars. It is not always compulsory to remove the existing cover sometimes if cover concrete is not much damaged then jacketing can be provided over the actual element. Concrete jacketing can be done on column, beams and slabs as well. Concrete jacketing is a successful process to regenerate the strength of members but its success depends upon the monolithic behaviour of the member. The shear force should transmit between old structure and concrete jacket. For achieving monolithic behavior surface treatment is very important. For this epoxy bonding agent are applied after roughening up old and new concrete. Steel connectors are also used to facilitate monolithic behavior and transmission of shear forces between old and new concrete. Concrete jacket should be at least $100 \mathrm{~mm}$ thick and of higher compressive strength than the old existing one. If this is not possible then it should be at least equal to the compressive strength of the old concrete. If possible then all four sided jacket should be given to maintain the symmetry, centre of gravity and neutral axis as before. Reinforcement that is provided in the concrete jacketing process must be carefully calculated and should pass all the checks of designing process.

\section{SPECIFICATION FOR REPAIR}

\section{Epoxy Resin Grout}

Epoxy Resin Grout (non shrink free flow low viscosity solvent free epoxy grouting required) or (high molecular thermo set polymer grouting) providing and injecting low viscosity solvent free epoxy. in the ratio of resin and hardener by grouting pump at a pressure @ 3-6 kg/ $\mathrm{cm}^{2}$ or as instructed by eic etc complete. After grouting is completed after 24 hours, cut the nipples and seal it with polymermodified mortar as per specifications given above. Considering $200 \times 200 \mathrm{~mm}$ grid on honeycomb areas and $150 \mathrm{~mm} \mathrm{c/c}$ along the crack.

\section{Polymer (Styrene Butadiene Rubber)}

First remove the loose concrete and cleaning the rebars with rust converter. Then clean the concrete with compressed air. Applying two coats of steel protective coating to the rebar. Applying bond coat of polymer modified bonding agent to the concrete and steel surface Applying polymer modified cement mortar to patch up the damaged concrete section in planks of $25 \mathrm{~mm}$ thickness. Curing the repaired surface for 3 days.

\section{Micro Fine Cement Grout}

Providing and injecting micro fine cement grout in the ratio by grouting pump at a pressure @ 3-7 kg/ $\mathrm{cm}^{2}$. Complete after grouting is completed after 24 hours, cut the nipples and seal it with polymer-modified mortar as per specifications given above. 


\section{CONDITION ASSESSMENT AND STRUCTURAL AUDIT BEFORE AND AFTER REPAIR OF FIRE DAMAGED STRUCTURE AND ANSYS SIMULATION OF COLUMN JACKETING}

\section{External Crack Filling}

Open the crack into $\mathrm{v}$ groove using proper mechanical tools. Ensure that the adjoining good plaster in not disturbed and damaged. Clean and moisten the groove. Providing and applying epoxy + silica sand 1: 2 proportion mortar, in the groove and finish at all heights, level and surface etc. complete. After 24 hours inspect and if required provide another leveling course over the same.

\section{Jacketing}

Drill the holes for fixing shear connector. Clean the holes force air and grout the shear connector with FOSROK or BASF or Equivalent Rebar chemical HILTI HY200 or HILTI Re300V3 or Equivalent. After fixing shear connectors clean the column surface with force air. Place the vertical reinforcement and rings as per drawing. Apply old and new epoxy bonding agent to existing column before doing new concrete (M30).

\section{TEST RESULT}

Table I. Carbonation Depth Test

\begin{tabular}{|c|c|}
\hline Carbonation depth & No. Of Reading \\
\hline $40 \mathrm{~mm}$ & $55 \%$ \\
\hline $80 \mathrm{~mm}$ & $45 \%$ \\
\hline
\end{tabular}

The Carbonation Test on all columns has been carried out. It was observed that because of poor quality of concrete resulted in rapid carbonation even beyond reinforcement.

Table II pH Test

\begin{tabular}{|c|c|c|c|}
\hline \multirow{2}{*}{$\begin{array}{c}\text { Sr. } \\
\text { No. }\end{array}$} & \multirow{2}{*}{ Description } & \multicolumn{2}{|c|}{$\begin{array}{c}\text { pH } \\
\text { (Before repair) }\end{array}$} \\
\cline { 3 - 4 } & & $\mathbf{4 0 m m}$ & $\mathbf{8 0 m m . ~}$ \\
\hline 1. & Column C1 & 8.78 & 9.91 \\
\hline 2. & Column C2 & 8.92 & 9.72 \\
\hline 3. & Column C3 & 8.69 & 9.89 \\
\hline 4. & Column C4 & 9.38 & 10.22 \\
\hline 5. & Column C5 & 9.57 & 10.37 \\
\hline 6. & Column C6 & 9.82 & 10.51 \\
\hline 7. & Column C7 & 9.39 & 10.43 \\
\hline 8. & Column C8 & 9.87 & 10.81 \\
\hline
\end{tabular}

The $\mathrm{pH}$ test of all columns has been carried out. Due to rapid carbonation during fire it is found that ph has also considerably dropped down.

Table III. Half Cell Potential Test

\begin{tabular}{|l|l|l|l|}
\hline & & \multicolumn{3}{|c|}{$\begin{array}{l}\text { Half Cell Potentiometer Test } \\
\text { (Before repair) }\end{array}$} \\
\cline { 3 - 4 } No. & \multirow{2}{*}{ Description } & Half Cell Readings (mV) & $\begin{array}{l}\text { Avera } \\
\text { ge } \\
\text { (mV) }\end{array}$ \\
\hline 1. & Column C1 & $\begin{array}{c}-349,-339,-331,-282,- \\
231,-231,-224,-217 .\end{array}$ & -264 \\
\hline 2. & Column C2 & $\begin{array}{l}-318,-315,-311,-251,- \\
242,-241,-232,-221 .\end{array}$ & -260 \\
\hline 3. & Column C3 & $\begin{array}{c}-350,-339,-328,-309,- \\
301,-290,-275,-264 .\end{array}$ & -302 \\
\hline 4. & Column C4 & $\begin{array}{c}-362,-358,-343,-335,- \\
255,-240,-231,-213 .\end{array}$ & -283 \\
\hline
\end{tabular}

\begin{tabular}{|c|c|c|c|}
\hline $\begin{array}{c}\text { Sr. } \\
\text { No. }\end{array}$ & Description & $\begin{array}{l}\text { Half Cell Potentiometer Test } \\
\text { (Before repair) }\end{array}$ \\
\hline 5. & Column C5 & $\begin{array}{c}-401,-399,-318,-300,- \\
297,-257,-248,-245 .\end{array}$ & -301 \\
\hline
\end{tabular}

In this test after fire it was observed that the range of corrosion potential measured from -169 to -401 and lesser $\mathrm{pH}$ values concrete indicative of $80 \%$ probability that corrosion is active.

Table IV. Ultrasonic Pulse Velocity Test

\begin{tabular}{|c|c|c|c|c|c|}
\hline \multirow{2}{*}{ No. } & \multirow{2}{*}{ Description } & \multirow{2}{*}{$\begin{array}{l}\text { No. of } \\
\text { Points }\end{array}$} & \multicolumn{3}{|c|}{$\begin{array}{c}\text { Ultrasonic Pulse } \\
\text { Velocity }(\mathrm{Km} / \mathrm{Sec})\end{array}$} \\
\hline & & & Max. & Min. & $\begin{array}{c}\text { Avera } \\
\text { ge }\end{array}$ \\
\hline \multicolumn{6}{|c|}{ Basement } \\
\hline \multicolumn{6}{|c|}{ Column C1 } \\
\hline \multirow{2}{*}{1.} & $\begin{array}{l}\text { (Before } \\
\text { repair) }\end{array}$ & 8 & 2.76 & 2.35 & 2.6 \\
\hline & $\begin{array}{c}\text { (After } \\
\text { jacketing) }\end{array}$ & 8 & 4.13 & 3.67 & 3.9 \\
\hline \multicolumn{6}{|c|}{ Column C2 } \\
\hline \multirow{2}{*}{2.} & $\begin{array}{l}\text { (Before } \\
\text { repair) }\end{array}$ & 8 & 2.81 & 2.45 & 2.7 \\
\hline & $\begin{array}{c}\text { (After } \\
\text { jacketing) }\end{array}$ & 8 & 4.24 & 3.41 & 3.8 \\
\hline \multicolumn{6}{|c|}{ Column C3 } \\
\hline \multirow{2}{*}{3.} & $\begin{array}{l}\text { (Before } \\
\text { repair) }\end{array}$ & 8 & 2.89 & 2.52 & 2.8 \\
\hline & $\begin{array}{c}\text { (After } \\
\text { jacketing) }\end{array}$ & 8 & 4.19 & 3.72 & 4.0 \\
\hline \multicolumn{6}{|c|}{ Column C4 } \\
\hline \multirow[t]{2}{*}{4.} & $\begin{array}{l}\text { (Before } \\
\text { repair) }\end{array}$ & 8 & 3.12 & 2.69 & 3.0 \\
\hline & (After repair) & 8 & 3.69 & 3.25 & 3.5 \\
\hline \multicolumn{6}{|c|}{ Column C5 } \\
\hline \multirow[t]{2}{*}{5.} & $\begin{array}{l}\text { (Before } \\
\text { repair) }\end{array}$ & 8 & 3.05 & 2.48 & 2.8 \\
\hline & (After repair) & 8 & 3.59 & 3.21 & 3.4 \\
\hline \multicolumn{6}{|c|}{ Column C6 } \\
\hline \multirow[t]{2}{*}{6.} & $\begin{array}{c}\text { (Before } \\
\text { repair) }\end{array}$ & 8 & 3.28 & 2.30 & 2.8 \\
\hline & (After repair) & 8 & 3.72 & 3.33 & 3.5 \\
\hline \multicolumn{6}{|c|}{ Column C7 } \\
\hline \multirow[t]{2}{*}{7.} & $\begin{array}{l}\text { (Before } \\
\text { repair) }\end{array}$ & 8 & 3.12 & 2.55 & 2.9 \\
\hline & (After repair) & 8 & 3.67 & 3.15 & 3.4 \\
\hline \multicolumn{6}{|c|}{ Column C8 } \\
\hline \multirow[t]{2}{*}{8.} & $\begin{array}{l}\text { (Before } \\
\text { repair) }\end{array}$ & 8 & 3.44 & 2.87 & 3.2 \\
\hline & (After repair) & 8 & 3.83 & 3.18 & 3.5 \\
\hline \multicolumn{6}{|c|}{ Beam B1 } \\
\hline \multirow[t]{2}{*}{9} & $\begin{array}{l}\text { (Before } \\
\text { repair) }\end{array}$ & 6 & 3.27 & 2.81 & 3.1 \\
\hline & (After repair) & 6 & 3.77 & 3.25 & 3.5 \\
\hline
\end{tabular}




\begin{tabular}{|c|c|c|c|c|c|}
\hline \multicolumn{7}{|c|}{ Beam B2 } \\
\hline \multirow{2}{*}{10} & $\begin{array}{c}\text { (Before } \\
\text { repair) }\end{array}$ & 6 & 3.53 & 2.92 & 3.3 \\
\cline { 2 - 6 } & (After repair) & 6 & 3.96 & 3.27 & 3.6 \\
\hline \multicolumn{7}{|c|}{ Beam B3 } \\
\hline \multirow{2}{*}{11} & $\begin{array}{c}\text { (Before } \\
\text { repair) }\end{array}$ & 6 & 3.39 & 3.05 & 3.3 \\
\cline { 2 - 7 } & (After repair) & 6 & 3.91 & 3.13 & 3.5 \\
\hline \multicolumn{7}{|c|}{ Beam B4 } \\
\hline \multirow{2}{*}{12} & $\begin{array}{c}\text { (Before } \\
\text { repair) }\end{array}$ & 6 & 3.75 & 2.59 & 3.2 \\
\cline { 2 - 7 } & (After repair) & 6 & 4.08 & 3.13 & 3.6 \\
\hline \multicolumn{7}{|c|}{ Beam B5 } \\
\hline \multirow{2}{*}{13} & $\begin{array}{c}\text { (Before } \\
\text { repair) }\end{array}$ & 6 & 3.62 & 2.97 & 3.3 \\
\cline { 2 - 7 } (After repair) & 6 & 4.18 & 3.46 & 3.7 \\
\hline \multicolumn{7}{|c|}{ Beam B6 } \\
\hline \multirow{2}{*}{14} & $\begin{array}{c}\text { (Before } \\
\text { repair) }\end{array}$ & 6 & 3.38 & 2.87 & 3.2 \\
\cline { 2 - 7 } & (After repair) & 6 & 3.86 & 3.13 & 3.5 \\
\hline
\end{tabular}

Ultrasonic Pulse Velocity test was carried out on all the members after fire (before repair) and found that values varied from 2.30 to 3.75 . This indicates that concrete of most of the members is porous in character and has severe and significant cracks. Hence, members are in doubtful condition and need repair.

After repair it was found that values varied from 3.13 to 4.24. This indicates that cracks and voids in concrete have been minimized and repaired. The new jacketed column also has negligible voids.

Table V. Rebound Hammer Test

\begin{tabular}{|c|c|c|c|c|c|c|}
\hline \multirow{2}{*}{$\begin{array}{l}\text { Sr. } \\
\text { No. }\end{array}$} & \multirow[t]{2}{*}{ Description } & \multirow{2}{*}{$\begin{array}{l}\text { No. of } \\
\text { Points }\end{array}$} & \multicolumn{3}{|c|}{$\begin{array}{c}\text { Rebound } \\
\text { Hammer Test } \\
(\mathrm{Km} / \mathrm{Sec})\end{array}$} & \multirow{2}{*}{$\begin{array}{l}\text { Compres } \\
\text { sive } \\
\text { Strength } \\
\text { (Mpa) }\end{array}$} \\
\hline & & & $\begin{array}{l}\text { Ma } \\
\text { x. }\end{array}$ & $\begin{array}{l}\text { Mi } \\
\text { n. }\end{array}$ & $\begin{array}{l}\text { Av } \\
\text { g. }\end{array}$ & \\
\hline \multicolumn{7}{|c|}{ Basement } \\
\hline \multicolumn{7}{|c|}{ Column C1 } \\
\hline \multirow{2}{*}{1} & $\begin{array}{l}\text { (Before } \\
\text { repair) }\end{array}$ & 16 & 26 & 18 & 22 & 15 \\
\hline & $\begin{array}{c}\text { (After } \\
\text { jacketing) }\end{array}$ & 16 & 34 & 26 & 30 & 26 \\
\hline \multicolumn{7}{|c|}{ Column C2 } \\
\hline \multirow{2}{*}{2} & $\begin{array}{c}\text { (Before } \\
\text { repair) }\end{array}$ & 16 & 28 & 18 & 24 & 16 \\
\hline & $\begin{array}{c}\text { (After } \\
\text { jacketing) }\end{array}$ & 16 & 32 & 26 & 28 & 24 \\
\hline \multicolumn{7}{|c|}{ Column C3 } \\
\hline \multirow{2}{*}{3} & $\begin{array}{l}\text { (Before } \\
\text { repair) }\end{array}$ & 16 & 26 & 20 & 22 & 15 \\
\hline & $\begin{array}{c}\text { (After } \\
\text { jacketing) }\end{array}$ & 16 & 36 & 26 & 30 & 26 \\
\hline \multicolumn{7}{|c|}{ Column C4 } \\
\hline \multirow[t]{2}{*}{4} & $\begin{array}{l}\text { (before } \\
\text { repair) }\end{array}$ & 16 & 30 & 24 & 26 & 20 \\
\hline & (after repair) & 16 & 34 & 26 & 30 & 26 \\
\hline \multicolumn{7}{|c|}{ Column C5 } \\
\hline 5 & (before & 16 & 30 & 22 & 25 & 18 \\
\hline
\end{tabular}

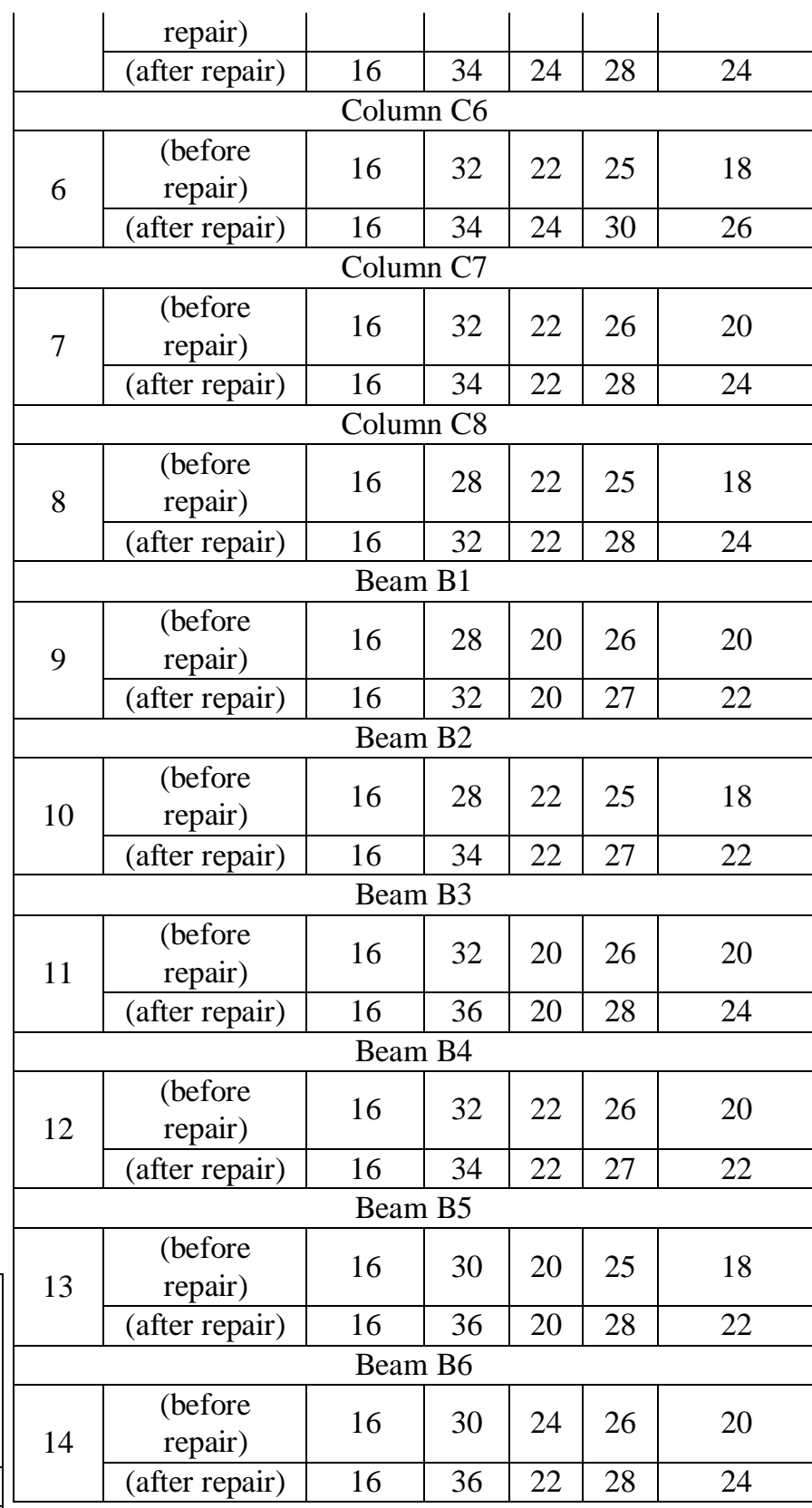

Rebound Hammer Test was carried out on all the members after fire (before repair) and it found that compressive strength of the members varied between M15 to M20 in correlation with carbonation effect on rebound number. Hence, members with lesser compressive strength have been jacketed or repaired accordingly based on the severity and residual strength of members.

After repair again this test was carried out and it was found that compressive strength varied from 22 to 26 . Hence, it was found that there is considerable increment in the compressive of members after jacketing and repair.

\section{ANSYS RESULT}




\section{CONDITION ASSESSMENT AND STRUCTURAL AUDIT BEFORE AND AFTER REPAIR OF FIRE DAMAGED STRUCTURE AND ANSYS SIMULATION OF COLUMN JACKETING}

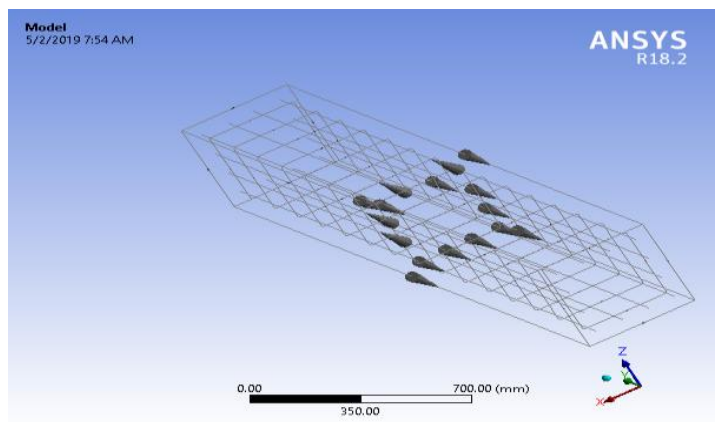

Fig. 6. Geometry of damaged column

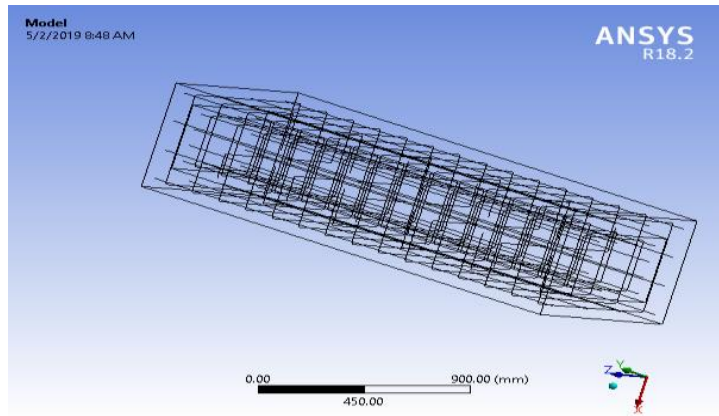

Fig. 7. Geometry of jacketed column

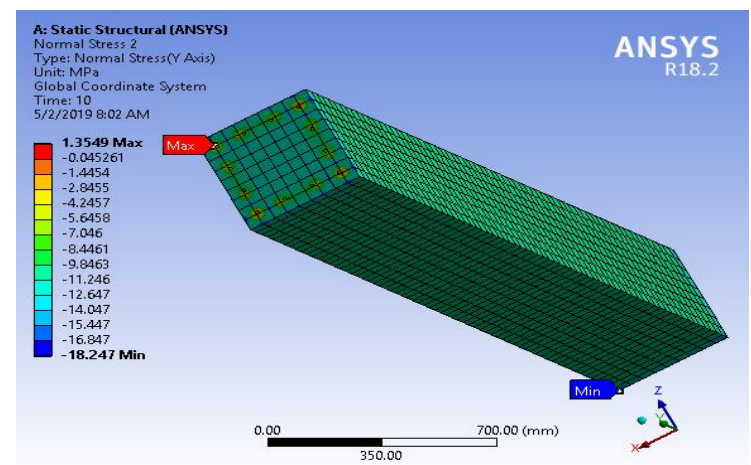

Fig. 8. Stress variation in damaged column.

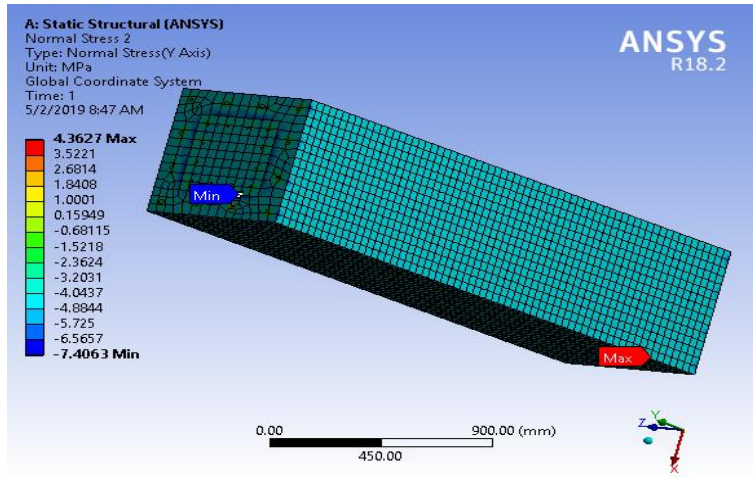

Fig. 9. Stress variation in jacketed column

Table VI. Normal Stress In Damaged Column

\begin{tabular}{|c|c|}
\hline Type & Normal Stress \\
\hline $\begin{array}{c}\text { Permissible Compressive Stress } \\
\text { (M 15 Concrete) }\end{array}$ & $6.9 \mathrm{MPa}$ \\
\hline Maximum Compressive stress & $18.247 \mathrm{MPa}$ \\
\hline Minimum Compressive stress & $0.045 \mathrm{MPa}$ \\
\hline & \\
Average Compressive Stress & $9.146 \mathrm{MPa}$ \\
\hline
\end{tabular}

Table VII. Normal Stress In Jacketed Column

\begin{tabular}{|l|c|}
\hline \multicolumn{1}{|c|}{ Type } & Normal Stress \\
\hline $\begin{array}{l}\text { Permissible Compressive Stress (M } \\
\text { 15 Concrete) }\end{array}$ & $6.9 \mathrm{MPa}$ \\
\hline $\begin{array}{l}\text { Permissible Compressive Stress (M } \\
\text { 25 Concrete) }\end{array}$ & $11.15 \mathrm{MPa}$ \\
\hline Maximum Compressive stress & $7.4063 \mathrm{MPa}$ \\
\hline Minimum Compressive stress & $0.6811 \mathrm{MPa}$ \\
\hline Average Compressive Stress & $4.0437 \mathrm{MPa}$ \\
\hline
\end{tabular}

The finite element software ANSYS is used to simulate the original column $(400 \times 400)$ and jacketed column (650x650) based on design process shown in fig 6 and fig 7 respectively.

It was observed that compressive stress developed in original column $(400 \times 400)$ is $9.146 \mathrm{Mpa}$ which is greater than 6.9 Mpa (permissible stress of M15) concrete shown in table 6. With reference to Clause 38.1 C of IS 456:2000.

In jacketed column (650x650) compressive stress developed is $4.0437 \mathrm{Mpa}$ which is less than permissible stress of M15 and M25 concrete 6.9Mpa and $11.15 \mathrm{Mpa}$ respectively shown in table 7. With reference to Clause 38.1 C of IS 456:2000. Hence, design of jacketing is safe.

\section{CONCLUSION}

Risk of fire is always there for all kind of buildings. Concrete buildings are no exception to it. Though concrete buildings are more resilient to fire than others but serious fire inflicted damage to the building. After fire is extinguished and structure is secured, condition survey and condition assessment was done over it. Visual inspection, hammering and chiselling techniques were used for condition survey. It give basic idea about the building condition. Afterwards condition assessment was done. In condition assessment, different tests are conducted and their values are recorded, to access the true condition of building. Different non-destructive testing and destructive testing techniques are used like Schmidt hammer test, UPV test, Half cell potential test, Carbonation test, $\mathrm{pH}$ test etc. were conducted. Here is lot of other testing techniques available to serve the cause but these techniques are selected after careful selection on the bases of purpose, economy, availability, accuracy, efficiency and damage to the building and environment. Use of NDTs for evaluation of concrete strength is beneficial but comes with accuracy of $65 \%$ to 85\% (if properly conducted).

Excessive temperature, alternate wetting and drying of concrete accelerated carbonation process of concrete during fire. Hence, residual strength and quality of structure was assessed on the basis of various non destructive testing such as ultrasonic pulse velocity , Rebound Hammer Carbonation, $\mathrm{pH}$ and Half cell potential test shown in table $1,2,3,4$ and 5 respectively. According to test results repair and retrofitting shemes was adopted and Jacketing has also been proposed to various column members. For jacketing 
design load has been calculated by staad pro software and accordingly jacketing has been designed using IS 15988:2013. After repair and jacketing of structure again non destructive test was done to assess the strength and quality of structure. Table 4 and 5 shows considerable increment in strength and quality of structure which is acceptable and safe. Finite element simulation of damaged column and jacketed column has been done using ANSYS software. After jacketing normal stresses in column are under permissible design stress, hence jacketed column and whole structure is safe.

\section{REFERENCES}

1. Haseeb Uz Zaman "Retrofitting and Rehabilitation of High Rise Fire Damaged Concrete Building",Study Course of Construction and Real-Estate Management, 2014, Helsinki Metropolia University of Applied Sciences.

2. IS 13311-1992, "Non destructive testing of concrete method of test" (Ultra Sonic Pulse Velocity), Part I : IS 13311.

3. IS 13311-1992, "Non destructive testing of concrete method of test"(Schmidt hammer) Part II :IS 13311 .

4. "Corrosion of metal in concrete" Part I: ACI-222R-89 report by ACI committee 222

5. “pH value” B.S. 5741-1991

6. IS-456-2000-“Plain \& RCC-Code of Practice”.

7. Mahmoud F. Belal a, Hatem M. Mohamed b, Sherif A. Morad $\mathrm{b}$, "Behavior of reinforced concrete columns strengthened by steel jacket", HBRC Journal (2014)

8. P. Lampropoulos and S. E. Dritsos, "Modeling of RC columns strengthened with RC jackets", Earthquake Engng Struct. Dyn. 2011; 40:1689-1705

9. IS 15988:2013, "Seismic Evaluation And Strengthening Of Existing Reinforced Concrete Buildings" -Guidelines, Bureau of Indian Standards, New Delhi, 2013

10. BS1881:Part 201:1986- "Guide to the use of nondestructive methods of test for hardened concrete".

11. CPWD, India: "Handbook of repair and rehabilitation of R.C.C buildings". 2002 